Mieczysław C. Paczkowski OFM

UMK, Toruń

DOI: http://dx.doi.org/10.12775/BPTh.2013.011

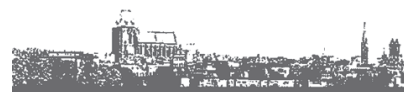

Biblica

et

Patristica

Thoruniensia

ISSN 1689-5150

\title{
Reinterpretacja postaci Hioba w starożytnym monastycyzmie chrześcijańskim
}

\section{Reinterpretation of the figure of Job in the ancient Christian monasticism}

Słowa kluczowe: Hiob (księga); monastycyzm (starożytny); patrystyczna interpretacja Biblii; duchowość monastyczna.

Key words: Job (book of); monasticism (ancient); patristic interpretation of the Bible; monastic spirituality.

Streszczenie. Artykuł przedstawia wyniki badań nad rozumieniem i praktycznym znaczeniem postaci Hioba w starożytnym monastycyzmie. Reinterpretacja monastyczna stanowi jeden z elementów historii interpretacji tej księgi biblijnej. W okresie patrystycznym Księga Hioba była raczej używana do prezentowania chrześcijańskiej etyki i duchowości, a nie doktryny teologicznej. Wydaje się, że używali jej raczej chrześcijańscy autorzy greccy niż łacińscy, przytłoczeni przez Moralia Grzegorza Wielkiego. Literatura monastyczna $\mathrm{z}$ tego okresu zauważa biblijną typologię wewnątrz kontekstu ascetycznego. W życiu sławnych mnichów i wielkich mistrzów duchowych charakterystyczne są takie cnoty jak cierpliwość, walka ze złem i wytrwałość w znoszeniu cierpienia. Wielu starożytnych mnichów widziało w postaci Hioba wzór dla szukających życia w obecności Bożej.

Abstract. This article presents the results of research in understanding and practical significance of the figure of Job in ancient monasticism. The monastic reinterpretation constitutes one of the elements of the history of interpretation of this biblical book in general. In the patristic period the book of Job, with its presentation of difficult theological views, has not been entirely congenial to the proponents of theological doctrine, but rather of Christian ethics and spirituality. Apparently the Greek Christian writers favored the book of Job. The Latins seem to have been overwhelmed by the Moralia of Gregory the Great. Monastic literature of that time notes the biblical typology within an ascetic context. Virtues such as patience, the struggle with evil and perseverance in bearing the sufferings appeared as a characteristic of famous monks and great spiritual masters. The biblical figures of Job is seen by the ancient monks as model for those seeking a life in God's presence. 
R iblijny Hiob powszechnie jest uznawany za „ikonę” cierpienia ${ }^{1}$. Dla tradycji B chrześcijańskiej księga Hioba zawierała dyskusję nad jedną z najstarszych prawd starotestamentalnej mądrości oraz przygotowywała na pełniejsze objawienie tajemnicy cierpienia w Nowym Testamencie ${ }^{2}$. Postawienie cierpienia $\mathrm{w}$ centrum uwagi nie oznacza jednak, że inne kwestie znikają z pola zainteresowania natchnionego autora. Dla czytelników Biblii księga Hioba nie była zwyczajną opowieścią „ku pokrzepieniu serc”, lecz zaproszeniem, aby spotkać się z „Bogiem żywym”, co pomaga przyjąć brzemię cierpienia ${ }^{3}$. Choć wydaje się ono niezrozumiałe i niezasłużone, skłania do ryzyka wiary w Bożą sprawiedliwość i dobroć ${ }^{4}$. Dla chrześcijan i Żydów historyczny Hiob w swoim literackim wcieleniu stał się przykładem cierpliwej i ufnej nadziei. Tak właśnie przedstawia go św. Jakub Apostoł w swoim liście: „Wychwalamy tych, którzy wytrwali. Słyszeliście o wytrwałości Hioba i widzieliście końcową [nagrodę za nią] od Pana; bo Pan pełen jest litości i miłosierdzia” (Jk 5,11).

Typologia postaci ze Starego Testamentu pojawiła się w chrześcijaństwie bardzo wcześnie. Jednak obok interpretacji dokonywanej według klucza chrystologicznego wybranych bohaterów biblijnych pojawiła się tendencja do przedstawiania ich jako exempla dla wiernych. Obok patriarchów czy proroków pojawili się również sprawiedliwi Starego Testamentu. Wskazywanie na to, że dana postać może być utożsamiona ze sławnym bohaterem biblijnym nie było bynajmniej rzadkim zjawiskiem, związanym wyłącznie z największymi przedstawicielami ruchu ascetycznego. Można stwierdzić, że cały monastycyzm był nacechowany biblijnością. Z przykładów biblijnych niewątpliwą popularnością cieszył się również Hiob. Według opinii Jana Chryzostoma „[Szatan] dotknął jego ciała nie po to, aby pogrążyć go w chorobie, ale aby zachwiać jego cnotą (arete)" ${ }^{\prime \prime}$.

1 Por. S. Jankowski, Zbawczy charakter cierpienia w świetle tekstów biblijnych, „Ateneum Kapłańskie” 555-556 (2001), s. 213-214. Papież Grzegorz Wielki uważał, że „błogosławiony Hiob nazywa się w naszym języku «Cierpiący», aby zarówno przez jego imię, jak i rany, wyrażała się męka naszego Zbawiciela” (cytat z Iz 53,4); Moralia in Job VI,1,1.

2 L. Stachowiak, Wstęp do Starego Testamentu, Poznań 1990, s. 442.

3 J. Guiton stwierdza, że księga Hioba „nie daje odpowiedzi na problem cierpienia, zła, ale skłania do postawy zaufania w mądrość i dobroć Boga”; Cytat wg H. Kołodziejczyk, Współczesne spojrzenie na tajemnicę cierpienia, Skrzynno - Henrykówka 2003, s. 130.

4 Na kanwie ST chrześcijanie odkrywali wartość oczyszczającą (por. Ps 65,10) i wychowawczą cierpienia oraz dostrzegli w cierpieniu oznaki Bożej łaskawości (Pnp 8,5). Dodatkowo bolesne i tragiczne doświadczenie pobudzało nieustannie do refleksji nad Bożym miłosierdziem. Por. H. Langkammer, Biblijne podstawy duchowości chrześcijańskiej, Wrocław 1987, s. 146.

5 Quod nemo laeditur 3. 


\section{Hiob i jego dzieje w interpretacji wczesnochrześcijańskiej}

U najwcześniejszych pisarzy chrześcijańskich postać Hioba jest niemal nieobecna ${ }^{6}$. Tylko Klemens Rzymski mówi o nim jako o świadku zmartwychwstania $^{7}$. Od III wieku coraz częściej tradycja chrześcijańska zaczęła sięgać po dzieje Hioba i jego świadectwo ${ }^{8}$. Klemens z Aleksandrii cytuje Hi 28,22 jako potwierdzenie zstąpienia Chrystusa do Otchłani ${ }^{9}$. Jest to jednak jeden z nielicznych odnośników do interpretacji chrystologicznej Hi w kręgu autorów aleksandryjskich. Zwykle historię Hioba tłumaczono metaforycznie ${ }^{10}$, odwołując się do teorii preegzystencji duszy i przekonań o jej upadku ${ }^{11}$. Tak więc ta postać stanowiąca żywe świadectwo „pedagogii cierpienia” ${ }^{12}$, jest raczej prefiguracją

6 Postać Hioba w pierwszych trzech wiekach opisuje L. Carnevale, Giobbe dallantichità al medioevo. Testi, tradizioni, immagini (Quaderni di „Vetera Christianorum” 33), Bari 2010, s. 56-69.

7 Por. 1 Clementis 26.

8 Odnośnie do tej tematyki por. M.-L. Guillaumin, Recherches sur l'exégèse patristique de Job, w: E.A. Livingstone (wyd.), Studia Patristica 12/1 (Texte und Untersuchungen 115), Berlin 1975, s. 304-308; [praca zbiorowa], Le Livre de Job chez les Pères, Strasbourg 1996; M. Perraymond, La figura di Giobbe nella cultura paleocristiana tra esegesi patristica e manifestazioni iconografiche, Watykan 2002.

9 Por. Stromata VI,45.

10 Przez wieki biblijna postać Hioba wymykała się analizom historycznym, chociaż znana była kraina Us, skąd pochodził. Biblijne genealogie podkreślają znaczenie tamtej krainy dla koczowników: imię Us nosił pierworodny syn Arama (por. Rdz 10,23), jak również Nahora (por. Rdz 22,21), czy pierwszy z potomków Diszana (por. Rdz 36,28). Ziemie, skąd pochodzili protoplaści Aramejczyków, leżały na styku trzech krain geograficznych: oazy Damaszku, Pustyni Syryjskiej i Doliny Jordanu. Była to wschodnia granica Ziemi Obiecanej, nazywana w starożytności Chauran (por. Ez 47,18). Teren ten przylega do opiewanego w Biblii Baszanu. Dzisiejsza arabska nazwa „Nukra” (t.j. spichlerz) wskazuje na urodzajność tej ziemi, zasilanej przez potok Jarmuk i inne dopływy Jordanu. Dawna granica między Baszanem a Galaadem wyznacza dziś częściowo granicę pomiędzy Jordanią a Syrią. Teren zajmują Druzowie, którzy zajęli miejsce Aramejczyków, Edomitów, Nabatejczyków i chrześcijańskich Ghassanidów. Do VI wieku zbocza gór był porośnięte dębowymi lasami, co tłumaczy biblijną nazwę Us - „ziemia zadrzewiona”. Życie koncentrowało się w żyznych dolinach, gdzie uprawiano pszenicę, winną latorośl i drzewa owocowe. Teren Us słynął zawsze z hodowli zwierząt: kóz, wielbłądów i koni. Opisywane przez tekst biblijny bogactwo Hioba miało więc swoje konkretne i racjonalne uzasadnienie.

11 Spuściznę orygeniańską aplikuje do Hi Dydym Ślepy; por. Fragmenta in Job 55, 16-60 (egzegza Hi 3,3).

12 Na temat oczyszczająco-wychowawczej roli cierpienia w ST por. X. Léon-Dufour, Wychowanie, w: idem (red.), Słownik teologii biblijnej, Poznań 1973, s. 1085-1089. 
chrześcijańskiego męczennika, a nie Zbawcy. Tym szlakiem musiał po części podążać Orygenes, którego komentarz do Hi nie zachował się do naszych czasów ${ }^{13}$. Szczególne znaczenie ma Hi 14,4-5. Ten fragment był cytowany w starożytności w celu ukazania różnicy pomiędzy Chrystusem, a innymi ludźmi odnośnie do kwestii grzechu ${ }^{14}$.

Różne formy życia monastycznego pojawiły się dopiero w IV wieku, a radykalna asceza nie była bynajmniej czymś powszechnym. W pierwszych trzech wiekach istnienia Kościoła nie podkreślano więc tak mocno aspektów pokuty i cierpliwości w cierpieniach cielesnych, których odzwierciedleniem była postawa Hioba. Wyjątek stanowi żyjący w III wieku Tertulian. Mówiąc o praktykach pokutnych nie przywołuje on historii męża z Us, lecz podkreśla o pewnych znakach zewnętrznej pokuty: „W worku i popiele leżeć, ciało mieć w brudzie i zaniedbaniu... [Pokuta], gdy ukazuje [człowieka] brudnym i zaniedbanym, tym bardziej go oczyszcza"15. Prześladowania, których doświadczali chrześcijanie sprawiły, że cnota cierpliwości, której niedościgły przykład dawał biblijny Hiob, stała się fundamentem ich postawy życiowej. Znacznie cierpliwości ${ }^{16}$ było związane $\mathrm{z}$ faktem, że stanowiła ona próbę wiary, poprzedzała ją i szła jej śladem ${ }^{17}$. W ujęciu Afrykańczyka cierpienia spowodowane prześladowaniami ukazują działanie szatana. Dzieje się to jednak za przyzwoleniem Bożym. „Wolą Boga jest poddanie próbie naszej wiary... [W tym celu] Bóg posługuje się jako narzędziem szatanem, który podczas realizacji tej próby posługuje się nieprawością... Prześladowanie jest próbą wiary, [a] niesprawiedliwość diabelska ma charakter instrumentalny... W żadnym przypadku bowiem szatan nie będzie mógł wystąpić przeciwko sługom Boga żywego, o ile Pan do tego nie dopuści, aby bądź tego tegoż diabła odtrącić przez wiarę wybranych, którzy zwycięsko przetrwali próbę, bądź wydać jego mocy tych, którzy upadłszy, przeszli na jego stronę. Masz przykład Hioba, którego diabeł nie mógłby zaatakować, gdyby od Boga nie otrzymał potrzebnej do tego władzy, i gdyby Pan nie oddał w jego moc posiadłości Hioba: «Oto - powiedział - cały jego majątek wydaję twojej mocy. Tylko na niego samego nie wyciągaj ręki» (Hi 1,12).

13 Por. Pseudo-Orygenes. In Job commentaria, PG 17, kol. 371-522. Echo interpretacji orygeniańskiej znajduje się w niektórych fragmentach dzieła Hilarego Tractatus in Job; por. Hieronim, De viris illustribus 100.

14 Por. Homiliae in Lev. VIII,3; Homiliae in Num. III,2; Homiliae in Isaiam III,2; Homiliae in Lucam 14; Commentarium in Rom. V,1; 5; 9; VII,18.

15 De paenitentia 9,$4 ; 6$.

16 O znaczeniu tej cnoty por. De patientia XIV,2; 4.

17 Por. M. Spanneut, Tertullien et les premiers moralistes africains, Paryż 1969, s. $37-38$. 
Wreszcie diabeł nie rozszerzyłby zakresu swojej władzy nad nim, gdyby Pan nie wyszedł naprzeciw jego prośbie i nie powiedział: «Jest w twej mocy. Życie mu tylko zachowaj» (Hi 2,6)"18.

Także Cyprian z Kartaginy przestawia Hioba jako przykład pokory, cierpliwości, hojności, wytrwałości w przeciwnościach i cierpieniach, stanowiących próbę dla sprawiedliwego ${ }^{19}$. To właśnie ten cierpiący sprawiedliwy ukazuje krótkotrwałość ludzkiej egzystencji ${ }^{20}$. Śladem biskupa Kartaginy poszli inni Ojcowie Kościoła, którzy w swoich homiliach i dziełach ascetycznych wskazywali na ten biblijny przykład. Tego typu interpretacja dominowała u Ojców greckich i łacińskich. Jak się wydaje autorzy wschodni częściej sięgali po Hi. Obok komentarzy pióra Atanazego ${ }^{21}$, Dydyma Ślepego ${ }^{22}$, Jana Chryzosto$\mathrm{ma}^{23} \mathrm{czy}$ innych ${ }^{24}$ istnieje również grecka Catena, zawierająca fragmenty dwudziestu czterech autorów starożytnych ${ }^{25}$. Większość z ich komentarzy do Hi zaginęła i zachowały się wyłącznie ich fragmenty.

18 De fuga in persecutione 2-3.

19 Por. Testimonia ad Quirinum III,1,6,14,54; De opere et eleemosynis 18.

20 Testimonia ad Quirinum III,89.

21 Fragmenta in Job (ex catenis); por. PG 27, 1343-1348.

22 Fragmenta ex catenis in Job; wyd. w: D. Hagedorn, U. Hagedorn i L. Koenen, Didymus der Blinde: Kommentar zu Hiob (Tura Papyrus), t. 3, 4. Bonn 1985; A. Henrichs, Didymos der Blinde: Kommentar zu Hiob (Tura-Papyrus). Papyrologische Texte und Abhandlungen, t. 1-2, Bonn 1968. Zob. również G. W. Marchal, Didyme de Blinde en zijn interpretatie van het boek Job. Sneek 1977.

23 Por. L. Dieu, Le commentaire de S. Jean Chrysostome sur Job, „Revue d'histoire ecclésiatique” 13 (1912), s. 640-658 ; S. Haidacher, Chrysostomus-Fragmente. A: Chrys-

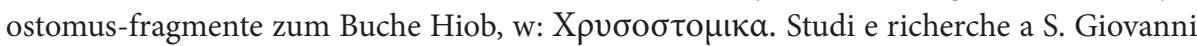
Crisostomo, t. 1, Rzym 1908, s. 217-234. Komentarzy do Hi nie brak także dziełach przypisywanych Złotoustemu; por. K. Samir -J. L. Scharpé, Les sermons sur Job du Pseudo-Chrysostome (CPG 4564 = BHG 939d-g) dans la version paléo-russe, „Orientalia Lovaniensia Periodica” 9 (1978), s. 167-173; K. Samir, Les sermons sur Job du Pseudo-Chrysostome (CPG 4564 = BHG 939d-g) retrouvés en arabe, „Orientalia Lovaniensia Periodica” 8 (1977), s. $205-216$.

24 Hezychiusz z Jerozolimy, por. C. Renoux, Hesychius de Jérusalem, Homélies sur Job: Version arménienne (PO 42/1-2); Teodor z Mopsuestii, In Jobum (por. PG 66, kol. 697-698); Olimpiodor z Aleksandrii, Commentarium in beatum Job (PG 93, kol. 11-409); U. i D. Hagedorn (wyd.), Olympiodor, Diakon von Alexandria: Kommentar zu Hiob (Patristische Texte und Studien 24), Berlin 1984; C. Osieczkowska, Note sur un manuscrit grec du livre de Job, no 62 du Musée byzantin d’Athenes, „Byzantion” 6 (1931), s. 223-228.

25 Por. P. Junius (wyd), Catena Graecorum Patrum in beatum Job collectore Niceta Heracleae Metropolita ex duobus mss. Bibliothecae Bodleianae codicibus, graece, nunc primum in lucem edita et latine versa, opera et studio Patricii Junii Bibliothecarii Regii, 
Ważnym przyczynkiem do poznania znaczenia postaci Hioba w chrześcijaństwie jest relacja hiszpańskiej pątniczki Egerii, która odwiedziła nie tylko najbardziej znane miejsca święte, ale także teren Zajordania. Działo się to na przełomie lutego i marca 384 roku, gdy znalazła się „na granicy Idumei i Arabii”, w mieście Karneas ${ }^{26}$. Egeria opisuje miejsca związane z historią Hioba i wspomina grotę $z$ inskrypcją nagrobną zawierającą jego imię $e^{27}$. „Stąd też wzniesiono Hiobowi ów kościół, który tu stoi, przy czym kamienia wraz z ciałem nie przeniesiono w inne miejsce, lecz zostawiono go tam, gdzie został znaleziony i ciało spoczywa pod ołtarzem"28.

Mimo pamiątek po Hiobie zastanawiano się nad historycznością tej posta$\mathrm{ci}^{29}$. Pytanie tego typu pojawiło się dosyć wcześnie w interpretacji tej biblijnej księgi ${ }^{30}$. Postać realna $\mathrm{z}$ pewnością pozwala głębiej interpretować rozważane teksty. W Onomasticonie Euzebiusza z Cezarei pod hasłem Ous (Us) ${ }^{31}$ znajduje

Londyn 1637 (= PG 64, kol. 505-635). Zob. także U. Bertini, La catena greca in Giobbe, „Biblica” 4 (1923), s. 129-142.

26 Por. Itinerarium 13,2.

27 Na temat pielgrzymek związanych z miejscami Hioba por. L. Carnevale, Giobbe dall'antichità al medioevo, s. 99-103.

28 Itinerarium 16,6.

29 Sulpicjusz Sewer tak oto streszcza dzieje biblijnego bohatera: „W przeciągu czasów pojawił się Hiob (por. Hi 1), który kierując się prawem natury doszedł do poznania Boga i wszelkiej sprawiedliwości, stał się bardzo bogaty w dobytek, ale i bardziej znany z tego, że ani nie uległ zepsuciu, gdy wszystko posiadał, ani się nie załamał po utracie wszystkiego. Albowiem gdy za sprawą diabła został pozbawiony majątku, a potem także i dzieci, to w końcu doprowadzonego do ostateczności, pokrytego wrzodami, nie można go było pokonać, by z powodu niecierpliwości zadanej przez boleść w jakieś mierze uległ grzechowi. Osiągnąwszy w końcu zapłatę Bożego poświadczenia, przywrócony do zdrowia, osiągnął na powrót wszystko podwójnie, co wcześniej utracił”. Chronica I,12,3

30 Grzegorz Wielki sądził, że pytania o historyczność postaci Hioba i jego dziejów są drugorzędne: „Zupełnie niepotrzebnie zastanawiamy się, kto tę księgę napisał, skoro przecież wierzymy, że jej autorem jest Duch Święty” (Moralia in Job, praef. 1,2). Snuje jednak rozważania na ten temat i twierdzi, że Hiob żył w czasach, kiedy w Izraelu rządzili sędziowie, a więc już po Mojżeszu. Wg Grzegorza Wielkiego autorem księgi jest sam Job (por. Moralia in Job, praef. 1,3). Znamienne jest, że w tradycji judaistycznej przez długi czas uważano, że Hiob istniał rzeczywiście. Dopiero w średniowieczu uznano, że ta postać jest fikcyjna, a celem opowiadania jest ukazanie ogólnego morału. Majmonides powtarzał z innymi rabinami, że „Hiob nie istniał i nie został stworzony”.

31 Odnośnik do Hi 1,1; por. E. Klostermann (wyd.), Eusebius Werke 3/1: Das Onomastikon der biblischen Ortsnamen GCS [= Die Griechischen Christlichen Schriftsteller der ersten Jahrhunderte] 11/1, Leipzig 1904 [nowe wyd. Hildesheim 1966], s. 142, 1. 3. 
się notatka potwierdzająca prastare tradycje ${ }^{32}$ : „Ojczyzna Hioba na terytorium Ausistis, imię to nosi także jeden z synów Ezawa” ${ }^{33}$. Tak więc obok wzmianki o sprawiedliwym cierpiącym ${ }^{34}$ jest także nawiązanie do genealogii Edomitów.

Pod imieniem Orygenesa zachował się komentarz do Hi przywrócony nieznanemu bliżej autorowi ariańskiemu o imieniu Julian ${ }^{35}$. We wprowadzeniu autor ukazuje, że księga została napisana przez Mojżesza. Jej cel i znaczenie wydobywa "dosłowna interpretacja”"36, chociaż użyte przez komentatora wyrażenie może oznaczać również sam tekst $\mathrm{Hi}^{37}$. Księga wskazuje na opatrzność Bożą skierowaną na wszystkich ludzi i przedstawia Hioba jako wzór cnoty do naśladowania ${ }^{38}$. Interpretacja, oprócz rygorystycznej dosłowności, jest również bardzo zwięzła. Mimo więc faktu, że nie jest to komentarz imponujących rozmiarów, obejmuje jednak całą księgę świętą. Na Arianina mieli wpływ egzegeci antiocheńscy, jak Lucjan z Antiochiii ${ }^{39}$, Diodor z Tarsu i Teodor z Mopsuestii. Mimo ich wpływu interpretacja tekstu nie jest rygorystycznie dosłowna. Wiele fragmentów z Hi jest odczytywanych w sensie symbolicznym, lecz interpretacja

32 Współczesna topografia potwierdza informacje Onomasticonu. Przy granicy jordańsko - syryjskiej położona jest wieś Sheikh Meskin. Jej arabska nazwa oznacza „cierpiący, opuszczony starzec". Cechy te miejscowa tradycja łączy z Hiobem, nazywanym przez muzułmanów prorokiem i sprawiedliwym Ajubem, jak głosi przekaz Koranu (por. sury $4,161 ; 6,84 ; 21,83 ; 38,40)$. We wsi wskazuje się symboliczny grób Hioba oraz kamień, gdzie cierpiący bohater biblijny obmywał swoje rany. O miano ojczyzny Hioba pretenduje także miejscowość Sheikh Sa’ad por. E. Klostermann (wyd.), Eusebius Werke 3/1: Das Onomastikon, s. 76, 1. 10.

33 Ogólne odnośniki do Rdz 36, 28 por. również por. E. Klostermann (wyd.), Eusebius Werke 3/1: Das Onomastikon, s. 76, 1. 10 i s. 112, 1. 3.

$34 \mathrm{O}$ „domu Hioba” por. E. Klostermann (wyd.), Eusebius Werke 3/1: Das Onomastikon, s. 142, 1. 3 .

35 Wyd. D. Hagedorn, Der Hiobkommentar des Arianers Julian (Patristische Texte und Studien 14), Berlin 1973. Zob. również P. Ferhat, Der Jobprolog des Julianos von Halicarnassos in einer armenischen Bearbeitung, „Oriens Christianus” 1 (1911), s. 26-31; R. Draguet, Un commentaire grec arien sur Job, „Revue d'histoire ecclésiatique” 24 (1924), s. 38-65.

36 Egzegezę Hi w komentarzach ariańskich przedstawia L. Carnevale, Giobbe dall'antichità al medioevo, s. 79-81.

37 Por. M. Simonetti, Między dosłownościa a alegorią. Przyczynek do historii egzegezy patrystycznej (Myśl Teologiczna 26), Kraków 2000, s. 318, przypis 274. .

38 Julian z Halikarnasu (Arianin), In Job I,2; IV,15.

39 Znana jest cześć arian dla Lucjana jako mistrza Ariusza. 
nie przechodzi w alegorię ${ }^{40}$. Swoje rozumowanie autor ilustruje cytatami z poetów pogańskich ${ }^{41}$.

Pewne punkty styczne z komentarzem Juliana zawiera Anonymus in $\mathrm{Job}^{42}$. Autor kładzie nacisk na retoryczny moralizm nie troszczy się wcale o rozwinięcie w sposób systematyczny typologii postaci Hioba, chociaż raz po raz ją przypomina. Hiob jest zapowiedzią Chrystusa, ale także jest figurą chrześcijan, którzy „w odnawiającej łasce przeszli przez wszystko i wszystkiemu stawili czoła. Nikt nie odpłacił złem za zło, lecz wypełnili nakaz Pański mówiący: «Miłujcie waszych nieprzyjaciół» (por. Łk 6,27)"43. Podobnie jak inni autorzy, także Anonim objawia tendencję do łagodzenia sensu pewnych sformułowań $\mathrm{Hi}$ i wyjaśniania antropomorfizmów ${ }^{44}$. To dzieło jest interesujące przede wszystkim odnośnie do pewnych elementów egzegezy chrystologicznej Hi, których brak w innych źródłach.

W przypadku Atanazego fragmenty dotyczące interpretacji Hi pochodzą prawdopodobnie $\mathrm{z}$ zaginionych homilii na ten temat. Żaden ze starożytnych autorów nie wspomina o komentarzach biblijnych pióra tego metropolity Aleksandrii ${ }^{45}$.

Ze względu na fragmentaryczność zachowanego komentarza do Hi przypisywanego Orygenesowi, reprezentatywna dla środowiska jest interpretacja Dydyma Ślepego ${ }^{46}$. Aleksandryjski erudyta przedstawia Hioba jako sprawiedliwego poddanego pokusie, co stanowi oczywistą linię interpretacyjną. W ten sposób ta postać biblijna urasta do rangi wzor odwagi, wytrwania i poddania się woli Bożej. Egzegeza dydymiańska ma przede wszystkim charakter moralny i parenetyczny ${ }^{47}$. Nie brak jednak rozważań o charakterze bardziej ogólnym lub chrystologicznym (Hiob jako symbol cierpiącego Chrystusa). Egzegeta aleksandryjski podkreśla, że wielkim dobrem jest martwić się z powodu grze-

40 Takie znamiona ma interpretacja wielkiego wieloryba (Hi 3,8) i smoka (Hi 26,13). Obrazy te odnoszone są do szatana; Por. In Job 36, 10; 161,15.

41 Por. np. In Job 301,13; 311,19. Zob. D. Hagedorn, Der Hiobkommentar des Arianers Julian (Patristische Texte und Studien 14), Berlin 1973, s. lxv-lxx.

42 Komentarz został opublikowany w PG 17, kol. 371-522.

43 Anonymus in Job 2.

44 Przykłady w: M. Simonetti, Między dosłownościa a alegorią. Przyczynek do historii egzegezy patrystycznej (Myśl Teologiczna 26), Kraków 2000, s. 321, przypis 287.

45 Por. J. Quasten, Patrologia, t. 2, Casale Monferrato 1983, s. 42.

46 Na ten temat por. M. Simonetti, Między dosłownością a alegorią, s. 215; L. Carnevale, Giobbe dall'antichità al medioevo, s. 70-71.

47 Zachował się część komentarz dotyczący Hi 1,1-6,29; 7,20-8,21; 9,10-15,22; 15,26$-16,2$. 
chu i podejmować wysiłki, gdy człowieka dotykają pokusy ${ }^{48}$. Bolesne próby i doświadczenia mają znaczenie wychowawcze, bowiem Bóg nie niszczy osoby, którą dotyka, lecz prowadzi go ku dobru ${ }^{49}$. W komentarzu Dydyma daje się zauważyć fakt, że pewne wyrażenia Hi nie mogły być przyjęte przez chrześcijanina w sposób dosłowny. Stąd pojawiła się konieczność uciekania się do alegorii w ich interpretacji, chociaż tekst Fragmenta in Job wydaje się najmniej „aleksandryjski” spośród zachowanych komentarzy tego autora ${ }^{50}$.

Dla autorów antiocheńskich Hiob jawił się jako konkretny przykład filozofii stoickiej i moralności. Stronice dzieł Ojców związanych z Antiochią ilustrują wzajemne przenikanie się tradycji moralności późnego cesarstwa i duchowości biblijnej początków chrześcijaństwa. Tak więc Hiob antycypuje typowo chrześcijańskie cnoty: „od cierpliwości po miłosierną miłość, od pokory po czystość, od skromności po czujność i ufność" ${ }^{51}$. Nic więc dziwnego, że dzieje męża z Us były wdzięcznym tematem dla kaznodziejów w wielkich metropoliach, jak i na terenach wiejskich. Reprezentatywna pod tym względem jest homiletyka Jana Chryzostoma.

Złotousty ukazywał wiernym szczytne ideały, lecz potrafił je tak opisywać, by były zrozumiałe i bliskie zwyczajnemu człowiekowi. Wielki kaznodzieja sięgał zarówno po natchnione teksty, jak i analogie zaczerpnięte z realiów codzienności. Chociaż nie ma pewności, że zachowane fragmenty dotyczące Hi są autorstwa Chryzostoma ${ }^{52}$, jednak wydają one się przesiąknięte do głębi jego duchem. Intencją kaznodziei w homilii pt. Adversus eos qui non adfuerant ${ }^{53}$ było wskazanie na konieczność kształtowania cnót moralnych. „Przede wszystkim powinniśmy oddalić się od zła, następnie zdobyć cnotę i w końcu zachować [ową] zdobytą cnotę. W tym punkcie musimy być szczególnie czujni, ponieważ złośliwość demona, zawistnego o nasze dobre czyny, atakuje w sposób najbardziej gwałtowny tych, którzy [mu] nie ulegają" ${ }^{54}$. Kaznodzieja na sposób oratorski opisuje rozliczne próby Joba. Obwieścił je zresztą w początkowej części homilii: „Nie było żadnego ludzkiego nieszczęścia, które by nie zniszczyło jego ciała. On jednak zatriumfował nad wszystkimi pułapkami [złego] i okazał

\footnotetext{
48 Por. Fragmenta in Job 88.

49 Tamże 167.

50 Por. M. Simonetti, Między dosłownością a alegorią, s. 216.

51 G. Ravasi [przeł. K. Rzepka], Hiob. Dramat Boga i człowieka, tom 1, Kraków 2004,

52 Por. Fragmenta in beatum Job (ex catenis), PG 64, kol. 506-635; Synopsis scripturae sacra: Job, PG 56, 361-368; In Job homilias IV. PG 56, kol. 563-582.

53 Por. PG 63, kol. 477-486.

54 Homilia IV (Adversus eos qui non adfuerant), 1.
} s. 191. 
się mocniejszy niż pociski diabła" ${ }^{55}$. Wielokrotnie jest powtarzane w kazaniu, że wszystkie nieszczęścia spadły na cierpiącego sprawiedliwego jednocześnie. Jego cnota jaśnieje jednak tak niezwykły blaskiem ze względu na fakt, iż żył on w okresie „zanim nastał \{czas] łaski i prawa”. Tak więc „to Job, który otworzył jako pierwszy szlak mądrości, tam, gdzie nikt nie dotarł, na morzu, na którym nikt jeszcze nie żeglował, w nieprzenikniętych mrokach zepsucia. Ćwicząc się w sposób najdoskonalszy we wszystkich cnotach, okazał się najczystszym" ${ }^{56}$.

Sposób działania diabła wobec Hioba ukazuje łaciński przekład homilii do Ps Orygenesa pióra Hieronima ze Strydonu. Bóg pozwolił, by szatan odebrał Hiobowi wszystko, a „pozostawił tylko język, aby bluźni1 ${ }^{57}$ i żonę, aby go kusiła" ${ }^{58}$. Orygenes/Hieronim ukazuje perfidię diabła, który uderzył w podstawowe prawo natury, w którym paradygmatem jest jedność pomiędzy mężem i żoną, nie zaś wyszukiwanie antagonizmów, czy punktów zaczepienia do walki między nimi ${ }^{59}$.

Pisarze łacińscy początkowo wykazywali mniejsze zainteresowanie księgą Hioba. Miało to związek z opóźnieniem studiów egzegetycznych na Zachodzie. Dopiero koniec IV i początek V wieku księga ta zacznie cieszyć się wśród komentatorów łacińskich powodzeniem. Taki stosunek do Hi nie wydawał się faktem przypadkowym, bowiem chronologicznie zbiega się z wyraźnym kryzysem, jaki zaczął trapić zachodnią część imperium począwszy od początku V wieku, ale którego oznaki można było zauważyć już wiele lat wcześniej. W burzliwych i naznaczonych głębokim kryzysem czasach człowiek w nieunikniony sposób pyta o sens cierpień, o sąd Boży nad światem, nad ludźmi i nad samym sobą. Księga Hioba, ze swym sprawiedliwym i doświadczonym przez nieszczęścia bohaterem, okazywała się szczególnie przydatna, aby stymulować tego typu refleksję.

55 Tamże. również Catechesis III,11 i Homilia in Sancta Cruce 1. Porównanie to odwołuje się do Ef 6,16 („W każdym położeniu bierzcie wiarę jako tarczę, dzięki której zdołacie zgasić wszystkie rozżarzone pociski Złego”).

56 Homilia IV (Adversus eos qui non adfuerant), 3.

57 „Musimy unikać mówienia złych rzeczy z obawy przed karą za grzechy... Jest napisane: «Nie unikniesz grzechu w gadulstwie» (Prz 10,19) i gdzie indziej: «Życie i śmierć jest w mocy języka» (Prz 18,21)"; Regula Benedicti VI,1-5.

58 Homiliae in Ps. XIV, 96,8. Jest to nawiązanie do najważniejszego zwycięstwa szatana, które odniósł w raju. Diabeł był całkowicie przeświadczony, że „mężczyznę może zawsze oszukać przy pomocy kobiety”.

59 Homiliae in Ps. XIV, 96,8. Na uwagę zasługuje wprowadzenie paralelizmu Ewa - Maryja. 
Wiadomo, że Hilary z Poitiers przepracował Komentarz do Hioba Orygene$\mathrm{sa}^{60}$. To właśnie $\mathrm{z}$ tej tradycji czerpie wiele tematów typologicznych, tak bardzo potrzebnych w polemice antyariańskiej. Z pewnością mniej rozpowszechniona była typologia Hiob - Chrystus, którą stosuje biskup Werony Zenon ${ }^{61}$. Ten typ interpretacji rozwijany w sposób systematyczny, stwarzał niejedną trudność. Bardziej naturalna była interpretacja Hioba jako typus chrześcijanina, który potrafi znieść próbę w postaci pokus podsuwanych mu przez diabła.

De interpellatione Job et David Ambrożego z Mediolanu ${ }^{62}$ ukazuje na przykładzie Hioba i króla Dawida kruchość ludzkiej egzystencji, nietrwałość powodzenia, władzy i potęgi człowieka ${ }^{63}$. Gorszącym wydaje się powodzenie grzeszników ${ }^{64}$. Rozważania tego typu miały prawdopodobnie swoje implikacje w wydarzeniach historycznych, których Mediolańczyk był świadkiem.

Ambrozjaster w Quaestio 118 de Job zajmował się Hiobem ${ }^{65}$, wskazując na niego jako na przykład sprawiedliwości i wytrwałości w cierpieniach. „Jak wielkiej godzien jest chwały, ten, kto przed [nastaniem] Prawa zachowywał je, a jak miał być przestrzegany przyszły nakaz ukazał nie słowami, lecz czynami”"66.

W przypadku Hieronima ze Strydonu ma się do czynienia z tłumaczem tekstu ${ }^{67}$, nic więc dziwnego, że wypowiada się on o wartości poszczególnych wersji językowych biblijnej księgi. Autor Wulgaty podchodzi raczej z rezerwą do tłumaczeń dokonanych przez Akwilę, Symacha i Teodocjona. Ich teksty po tym, jak „zajaśniała Ewangelia Chrystusa... za pomocą przebiegłego tłumaczenia, ukryły wiele tajemnic Zbawiciela" ${ }^{68}$. Z powodu trudności z kopiami tekstu biblijnego, Hieronim mówi nawet, że „podniósł Hioba ze śmietnika” ${ }^{69}$. Wszelkie trudności egzegeta łaciński rozwiązywał według swej metody odwoływania się do veritas hebraica ${ }^{70}$. Łacińskie tłumaczenie Hi stara się zachować wierność

60 Por. A. di Berardino, Patrologia, t. 3, Rzym 1983, s. 51.
61 Por. Sermones I,15.
62 Por. A. di Berardino, Patrologia, t. 3, Rzym 1983, s. 151-152. S
63 Ambroży odwołuje się do Ps 38 i 41.
64 Por. Ps 72.
65 Tekst w PL 35, kol. 2215-2422.
66 Quaestio 118 de Job.
67 Por. Liber Job; PL 28, kol. 1079-1122; Liber Job. Altera versio; PL, 29, kol. 61-114.
$68 \quad$ Liber Job. Prologus.
69
Istnieją również Commentarii in librum Job; PL 26, kol. 619-802. Por. P. de Lagarde, Des Hieronymus Übertragung der griechischen Übersetzung des Iob, „Mittheilungen” 2 (1887), s. 189-237.

70 Hieronim zgłębiał Słowo Boże przez kontakt ze środowiskiem semickim. Por. A. Penna, Principi e carattere dell'esegesi di S. Girolamo, Rzym 1950, s. 205-206. 
oryginałowi. Strydończyk jednak odwołuje się do Septuaginty, gdy musi rozwiązać niektóre problemy dotyczące wariantów tekstowych. Chodzi tu przede wszystkim o wzmianki dotyczące zmartwychwstania. Jego interpretacja jest na wskroś chrześcijańska, jak w Hi 19,25: „Scio enim quod Redemptor meus vivat". Redemptor to rzecz jasna odnośnik do Chrystusa. W innych przypadkach autor Wulgaty nie cofa się przed poprawianiem tłumaczenia greckiego, lecz wykorzystuje każdą okazję, by wskazać na wydźwięk teologiczny tekstu. Tam, gdzie tekst był niejasny lub uszkodzony, łaciński tłumacz proponował wersję w duchu eschatologii chrześcijańskiej ${ }^{71}$.

Niewątpliwą zasługą św. Hieronima jest podkreślenie aspektu ludzkiego historii Hioba ${ }^{72}$. Ponadto bohater biblijny jest raczej buntownikiem, a nie wyłącznie cierpliwym sprawiedliwym. Dzięki autorowi Wulgaty postać Hioba była postrzegana jakby na dwa sposoby: człowiek znoszący cierpliwie cierpienia i doświadczenia (Hiob w perspektywie pisarzy greckich) i stawiający pytania buntownik (Hiob „łaciński”). Tłumaczenie mnicha z Betlejem stanowiło zaskoczenie i wywołało w wielu duszach niepokój. Św. Augustyn wypominał Hieronimowi, że wielu odczuwa zagubienie w zetknięciu się z łacińską wersją $\mathrm{Hi}^{73}$.

Autorzy chrześcijańscy zwracali uwagę na pewne wzmianki biblijne, które stanowiły aluzję do postaci Hioba (Ez 14,14.20; Tb 2,12-15). Obok Noego i Daniela był on jednym z "trzech mężów sprawiedliwych"74. Wątek rozważań o "tria genera hominum" najpełniej ukazuje Augustyn identyfikujący Hioba z wiernymi żyjącymi w małżeństwie (plebs) $)^{75}$. Podobny typ interpretacji postaci Hioba można znaleźć u Orygenesa czy Cyryla z Aleksandrii ${ }^{76}$. Jednak to Doctor gratiae ją usystematyzował i jasno określił. Oprócz rozproszonych

71 Podobnie postępuje papież Grzegorz Wielki, interpretując Hi 42,10: „W ów dzień Boże błogosławieństwo nie tylko dusze nasze wypełni, ale również ciała nasze chwalebnie zmartwychwstaną"; Moralia in Job XXXV,14,25.

72 W oparciu o postulat soteriologiczny Hieronim podkreślał również człowieczeństwo Chrystusa: "Wyznajemy, że posiadał On prawdziwe ciało i prawdziwą duszę. Jeśli bowiem Pan nie posiadałby tego wszystkiego, co jest właściwe dla człowieka, nie odkupiłby go "; In Ps 108,31.

73 Por. Epistula 28,2; 71,2.

74 Chodzi głównie o tradycję prorocką, lecz o Hiobie wspomina także hebrajski tekst Syracha (por. Syr 49,9), zniekształcony w greckim przekładzie Septuaginty.

75 Enarrationes in Psalmos 132,5.

76 Por. G. Folliet, Les trois catégories de chrétiens a partir de Luc (17, 34-36), Matthieu $(24,40-41)$ et Ézéchiel $(14,14)$, w: Augustinus Magister (Études Augustiniennes 2), Paryż 1955, s. 633. 
fragmentów egzegezy Hi, św. Augustyn pozostawił Adnotationes in $J_{0} b^{77}$ i jedno kazanie na temat Hi $1,6^{78}$. Pierwsze dzieło stanowią notatki na marginesie księgi, które zostały przepisane i zebrane w jednym tomie. Hippończyk określił te swoje rozważania jako „słodkie, dla tych którzy są w stanie je zrozumieć”79. Szeroki opis życia i postępowania Hioba znaleźć można także w innych jego dziełach. W licznych i trudnych doświadczeniach Hiob musiał walczyć o zachowanie wierności Bogu. „Święty Hiob siedział na kupie gnoju, a biegł drogą \{Bożą]... Utraciwszy wszystko, pozostał z żoną, która go kusiła i Bogiem, który nim rządził"80. Najistotniejszym dla Augustyna jest stan ducha cierpiącego sprawiedliwego i bogactwo jego serca. Przyjął trudy doświadczeń i znosił z pokorą wszelkiego rodzaju „ciosy bicza”, wymierzane mu za przyzwoleniem Boga i nawet słowem nie sprzeciwił się Jego woli ${ }^{81}$.

Tej samej księdze biblijnej poświęcił krótki komentarz Julian z Eklanum ${ }^{82}$. Jego egzegeza odchodzi jednak od tradycyjnych schematów typologicznych i na pierwszym miejscu stawia racjonalną analizę znaczenia tekstu biblijnego ${ }^{83}$.

Nie sposób nie wspomnieć o dziele papieża Grzegorza Wielkiego Moralia in $\mathrm{Job}^{84}$. W tekście $\mathrm{Hi}^{85}$ komentator zauważył przede wszystkim wątki moralne, choć biblijna księga dostarczyła mu również okazji do podejmowania szeregu szczegółowych tematów biblijnych, ascetycznych i teologicznych. Moralia odegrały kluczową rolę w średniowieczu nie tylko w kwestii studiów

77 Wyd. PL 34, kol. 825-886. Na temat Adnotationes por. A. Di Berardino, Patrologia, t. 3, s. 358 .

78 Por. Sermo de eo quod scriptum est in Job, cap. 1,6; PL 38, kol. 100-106.

79 Retractationes 2,13.

80 Enarratio in Ps 103 (4),7.

81 Por. tamże. Na temat „walki z pokusami”, której przykładem był Hiob por. D. Zagórski, Commendavit nobis Dominus oves suoas. Pasterska troska o wiernych $w$ Sermones św. Augustyna, Toruń - Pelplin 2013, s. 338-339.

82 Expositio libri Jobi; PLS 1, kol. 1573-1679 (wyd. A. Amelli); L. De Conink, Juliani Aeclanensis Expositio libri Iob, w: CCL 88.

83 Por. A. Vaccari, Un commento a Giobbe di Giuliano di Eclana. Rzym 1915; C. Weyman, Der Hiobkommentar des Julianus von Aeclanum, „Theologische Revue” (1916), s. $241-248$.

84 Por. M. Adriaen (wyd), S. Gregorii Magni Moralia in Iob, CCSL 143, 143 A, 143 B, Turnhout 1979-1985. Zob. L. Nieścior (red.) - T. Fabiszak, A. Strzelecka, R. Wójcik (przekł.), Grzegorz Wielki. Moralia. Komentarz do Księgi Hioba, t. 1: księgi I-V, t. 2: księgi VI-X, t. 3: księgi VI-X, t. 4: księgi XVII-XXII (ŹM 39, 41,44, 63), Kraków-Tyniec 2006-2013.

85 Por. P. Salmon, Le texte de Job utilisé par S. Grégoire dans les “Moralia”, w: A. Metzinger (red.), Miscellanea Biblica et Orientalia R. P. Athanasio Miller O.S.B... completis LXXX annis oblata (Studia Anselmiana 27-28), Rzym 1951, s. 187-194. 
biblijnych, ale także były ważnym przyczynkiem w refleksji etycznej i doktrynalnej. Wieki średnie otrzymały obszerny podręcznik teologii ascetycznej i moralnej ${ }^{86}$.

Rozważania papieża Grzegorza Wielkiego to dopełnienie interpretacji postaci Hioba. Starotestamentalny sprawiedliwy zapowiadał Chrystusa i Jego cierpienia. Autor Moraliów rozciągnął chrystologiczną interpretację postaci Hioba rozciągnął na Kośció ${ }^{87}$. „Ciało tego Hioba zostało wyniszczone ranami, ponieważ nasz Zbawca nie wzgardził tym, by zostać przybitym gwoździami do krzyża. Otrzymał zaś rany od samych stóp aż do czubka głowy, ponieważ kusiciel, zionący prześladowczym szałem, zranił Kościół święty, który jest Jego ciałem, nie tylko w najniższych i najodleglejszych członkach, lecz nawet w najwyższych"88. Dwa stulecia po Ambrożym i Augustynie postać Hioba na nowo przywołała tak dobitnie obraz umęczonego i zwycięskiego Chrystusa. Papież Grzegorz rozwinął swoją refleksję także w kierunku eklezjologicznym. „Błogosławiony Hiob będący typem Kościoła świętego przemawia bądź to głosem jego ciała, bądź też głosem jego Głowy i gdy mówi o członkach Kościoła, natychmiast wznosi się do słów, które wypowiada Głowa. Dlatego czytamy: «To cierpiałem, choć nie ma nieprawości w ręce mojej, gdyż czyste były me prośby do Boga»... [Chrystus] zniósł dla naszego zbawienia wszystkie boleści krzyża. On sam jeden przed wszystkimi innymi zanosił czyste prośby do Boga i modlił się w czasie męki krzyżowania za swoich prześladowców mówiąc: «Ojcze, przebacz im, bo nie wiedzą, co czynią»" ${ }^{89}$. Grzegorz ma tu na myśli nie tylko prześladowania, jakich doznaje Kościół, ale również grzechy, którymi ranią Kościół jego członkowie ${ }^{90}$.

Chronologicznie opracowywanie przez Grzegorza Wielkiego komentarza do Hi zbiegło się z młodością Mahometa, Beduina z arabskiego szczepu Quraysh, twórcy religii muzułmańskiej. Chrześcijańska tradycja, szczególnie sy-

86 Por. Por. R. Wasselynck, Les "Moralia in Job" dans les ouvrages de morale du haut moyen âge latin, „Recherches de théologie ancienne et médiévale” 31 (1964), s. 5-31.

87 Grzegorz Wielki przywołał Pawłowy obraz Kościoła jako Ciała Chrystusa i Zbawiciela jako Głowy Kościoła. Por. J. Salij, Papież Grzegorz Wielki jako komentator Ksiegi Hioba, w: P. Mitzner i inni (red.), Hiob biblijny. Hiob obecny w kulturze, Warszawa 2010, s. 74.

88 Moralia in Job VI,1,1.

89 Moralia in Job XIII, 21-22.

90 Por. J. Salij, Papież Grzegorz Wielki jako komentator Księgi Hioba, s. 74. 
ryjska, miała znaczny wpływ na wczesny islam ${ }^{91}$. Następowała swego rodzaju translatio miejsc kultu rozsianych po Bliskim Wschodzie i ich islamizacja ${ }^{92}$.

\section{Przykład Hioba: walka duchowa i wytrwałość w cierpieniu}

Monastycyzm wyrażał tendencję do szukania osobistych związków z Bogiem, realizowanych $\mathrm{z}$ radykalną konsekwencją. Podstawowe zasady tego sposobu życia wykształciły się w epoce patrystycznej, w okresie życia i działalności wielkich Ojców Kościoła Wschodniego i Zachodniego. Pierwsi asceci chrześcijańscy szukali w Biblii inspiracji i wyodrębniali postacie, na których mogliby się wzorować. Wzoru i podstawy wszelkiej ascezy chrześcijańskiej należy szukać najpierw w osobie i nauce Jezusa. „Ojciec mnichów” - Antoni Egipski był przecież tym, który przede wszystkim naśladował Chrystusa ${ }^{93}$. Ponieważ jednak Biblia była w monastycyzmie punktem odniesienia, nie mogło zabraknąć wielu innych przykładów z niej zaczerpniętych. Pismo Święte było dla mnichów podstawą edukacji, formacji i wykładnią postępowania, a więc swego rodzaju "podręcznikiem” życia ascetycznego ${ }^{94}$. Z pewnością istniał specyficzny typ interpretacji biblijnej w kręgach monastycznych, odznaczającej się pragmatyzmem ascetycznym. Chrześcijanie odchodzący na pustynię postrzegali Pismo Święte w kontekście duchowych poszukiwań. Nie można go było sprofanować przez nierozsądne spekulacje. Tak więc obok wielkiego szacunku do świętych tekstów istniała głęboka podejrzliwość w stosunku do wszelkiej spekulacji czy nawet rozprawiania o tajemnicach zawartych $\mathrm{w}$ natchnionych słowach. Mądrość natchnionych tekstów nie potrzebuje uczonych dysput, lecz woli, by wcielić ją w życie. Jednak mimo tego faktu częstotliwość cytowania Biblii w Apoftegmach, gdzie odnośniki do tekstów biblijnych są raczej sporadyczne ${ }^{95}$.

91 Jeden z muzułmanów powiedział: „Syria to kraj, który przez długi czas zajmowali chrześcijanie... i jest tam wiele pięknych kościołów należących niezmiennie do nich i znanych ze swej wspaniałości”; M.J. Goeje (wyd.), Al-Muqaddasi. Descriptio imperii moslemici, Frankfurt 1992 [reprint], s. 159.

92 Koran wspomina Joba (Ajuba) czterokrotnie. To krótkie fragmenty dotyczące objawienia Boga w ST. Por. L. Carnevale, Giobbe dallantichità al medioevo, s. 115-119.

93 Por. Atanazy, Vita Antonii 2.

94 Na temat lektury indywidualnej i wspólnotowej Biblii por. G.M. Colombas, Bibbia e monachesimo, w: G. Pelliccia-G.C. Rocca (red.), Dizionario degli Istituti di Perfezione, t. 1, Rzym 1974, kol. 1456.

95 Por. B. De Margerie, Introduzione alla storia dell'esegesi. Padri greci e orientali, t. 1, Rzym 1983, s. 150. Autor pokreśla, że spośród 918 sentencji Ojców Pustyni tylko niecałe 150 zawiera reminiscencje i aluzje do tekstów biblijnych. 
Tradycja ascetyczna zwykle nawiązywała do wielkich postaci monastycyzmu, fundatorów i kierowników duchowych ${ }^{96}$. Pierwowzorów swego sposobu życia mnisi doszukiwali się także w postaciach biblijnych ${ }^{97}$. Hiob stał się wzorem, na który patrzono z podziwem i pragnieniem naśladowania ${ }^{98}$. Tak było jednak nie tylko w przypadku mnichów, bowiem dl Grzegorza Wielkiego ta postać biblijna przedstawia życie osób żyjących w małżeństwie (bonorum coniugatorum $)^{99}$.

Literatura monastyczna dostarcza wielu przykładów powoływania się na życie i postępowanie Hioba, będącego niekwestionowanym wzorem dla ascetów. Abba Jan Pers spodziewał się wiecznej nagrody dlatego, że stał się "gościnny jak Abraham ${ }^{100}$, łagodny jak Mojżesz... wytrwały jak Hiob... samotny jak Jan [Chrzciciel]"101. Ten Apoftegmat to wykaz tradycyjnych cnót monastycznych, w którym niepoślednią rolę odgrywa wytrwałość. Tradycja monastyczna odwoływała się także do „paradygmatu „trzech sprawiedliwych z Ez 14,14.20. „Ubóstwo, utrapienie, surowość życia i post: to są narzędzia rzemiosła monastycznego... Noe oznacza ubóstwo, Hiob cierpienie, Daniel roztropność"102.

W opinii pisarzy z kręgów ascetycznych postać Hioba to uniwersalny przykład w praktykowaniu każdej z najważniejszych monastycznych cnót. „Brat spytał starca: «Cóż mam czynić, gdyż duch mój słabnie przy niewielkim tru-

96 Por. N. Füglister, L'expérience de Dieu dans et selon l'Écriture: le prophète comme un prototype, w: L'expérience de Dieu dans la vie monastique, Abbaye Sainte-Marie de la Pierrequi-vire 1973, s. 93.

97 Dla mnichów integralną postawę człowieka oddanego Bogu reprezentuje „ojciec naszej wiary” - Abraham. Ważne przykłady dla życia ascetycznego znajdywano w Mojżeszu i w prorokach Starego Testamentu, szczególnie w Eliaszu i Elizeuszu, którzy prowadzili odosobniony, surowy tryb życia w ustawicznym dialogu z Bogiem. Mieli oni także swoich uczniów. Jeszcze bliższym wzorem takiego życia był święty Jan Chrzciciel. Wizję pism nowotestamentowych, w których osoba Poprzednika Zbawcy zlewa się z postacią proroka Eliasza, potwierdzają wczesne źródła chrześcijańskie. Z Nowego Przymierza prezentowano apostołów Piotra i Pawła, którzy kierowali ludzi ku Bogu prawdziwemu, oddalając ich od bożków. Por. M. Kanior, Historia monastycyzmu chrześcijańskiego, t.1, Kraków 1993, s. 17; V. Desprez, Początki monastycyzmu. Dzieje monastycyzmu do Soboru Efeskiego (431) (Źródła Monastyczne 21), t. 1, Kraków-Tyniec, 1999, s. 109.

98 Wg Grzegorza Wielkiego swoją postawą Hiob zawstydzał członków ludu Bożego, w tym również osoby duchowne; por. Moralia in Job, praef. 2,5.

99 Por. Moralia in Job I,14,20; In Ezechielem I,8,10 i II,4,5.

100 O gościnności jako cnocie monastycznej por. Bazyli Wielki, Regulae fusius tractatae 32 a.

101 Apophtegmata Patrum (seria alfabetyczna) 419.

102 Apophtegmata Patrum (seria alfabetyczna) 634. Por. również seria systematyczna I,14. 
dzie?» Starzec odrzekł: «Czy nie podziwiamy Józefa [Egipskiego] ${ }^{103}$... Przypatrzmy się i Hiobowi, iż bojąc się Boga został niezłomny do końca ${ }^{104}$ i nikt nie zdołał odwrócić go od nadziei pokładanej w Bogu» (por. Hi 1,22; 19,25-27)"105. W pouczeniach Ojców pustyni Hiob jawił się jako człowiek wyjątkowy, o którym pisano, że nigdy nie uległ grzechowi.

Ustawodawca monastycyzmu zachodniego św. Benedykt streścił wcześniejszą tradycję mówiąc, że pustelnik to ten, kto po przejściu koniecznego ćwiczenia potrafi już samotnie walczyć $z$ szatanem ${ }^{106}$. Nie jest to wyłącznie negatywne ujmowanie życia wewnętrznego, bowiem ascezę postrzegano nie tylko jako przeciwstawianie się bezosobowo pojętym słabościom, lecz jako morderczą walkę z szatanem ${ }^{107}$. Tego typu topos literacki był powszechny w literaturze monastycznej. W kręgach wiernych świeckich, jak również wśród ascetów, którzy opuścili świat, uważano wszelkie zmagania ze złem za rzecz oczywistą, gdyż to właśnie z poduszczenia diabła człowiek w raju przekroczył zakaz Boga. Tej walce służą ustanowione przez Boga prawa. Przedstawiano więc ludzi niezwykłego formatu, którzy nie ulegli w boju z szatanem. W Starym Przymierzu był nim w pierwszym rzędzie Hiob, o którym pisano, że nigdy nie uległ grzechowi. Biografowie mnichów ukazywali na przykładzie swoich bohaterów możliwość i przebieg walki człowieka z szatanem, aż do ostatecznego zwycięstwa. Już Platon uważał, że „życie bez prób nie jest warte przeżycia” ${ }^{108}$. Próba, jakiej poddany został Hiob, wykazała jego pokorę i wiarę. Ojcowie podawali zresztą liczniejsze przykłady probatio fidei sprawiedliwych ze Starego Testamentu i interpretowali je jako prefigurację wymogów ewangelicznych ${ }^{109}$. Już Klemens z Aleksandrii uważał, że „doskonały chrześcijanin” powinien pragnąć próby: „Panie, daj mi sposobność i wystaw mnie na próbę"110. Szczególnie doświadczani byli właśnie

103 Nawiązanie do Rdz 39-40.

104 Reguła Mistrza mówi o cnocie wytrwałości „aż do końca”; por. Regula Magistri V,10; IV,10.

105 Apophtegmata Patrum (seria alfabetyczna) 676. Por. również seria systematyczna XXI,29.

106 Regula Benedicti 1,1-5.

107 W walce $\mathrm{z}$ szatanem Hiob okazał się wojownikiem wręcz heroicznym i „zadawał ciosy o wiele mocniejsze niż te, które otrzymywał... Pokornie znosząc udrękę, pomnożył dobra niebieskie"; Moralia in Job II,18,32.

108 Obrona Sokratesa 38a.

109 Por. H. Jaeger, Examinatio, w: Dictionnaire de Spiritualité Ascétique et Mystique, Doctrine et Histoire, t..4, Paryż 1961, kol. 1849-1851.

110 Stromata IV,7,55. „Cierpienia zachęciły was do walki, w której wir rzuciliście się z mocą i stałością, zespoleni w najwyższym stopniu z duchem gotowym i pobożnym... 
mnisi, bowiem „nie można zdobyć mądrości bez walki”"111. Życie mnisze, według świadectwa jednej z homilii Jana Chryzostoma, stanowiło przeciwieństwo codzienności zwykłych ludzi ${ }^{112}$. Niezwykłe umartwienia wielu mnichów być może zadziwiały mieszkańców miast i wsi, ale budził również wielką ciekawość i podziw. Stan fizyczny ascetów był pretekstem do pouczeń, że to nie wygląd zewnętrzny i piętno choroby są wyznacznikiem cnoty lub niegodziwości.

Dostrzegano to wcześniej, zanim narodził się monastycyzm. Klęska Hioba w dość popularnym ujęciu patrystycznym to droga do ukazania dobroci Boga. Wszelkie nieszczęścia, które zsyłał na niego diabeł, prowadziły sprawiedliwego męża do Boga. W końcu Bóg rozmawia z Hiobem jak przyjaciel z przyjacielem i jest w stanie obrócić dla dobra człowieka wszystkie nieszczęścia czynione przez szatana. Warunkiem było dochowanie wierności Bogu ${ }^{113}$. Według Doroteusza z Gazy asceta nie powinien dziwić się temu, że znalazł się $\mathrm{w}$ niesprzyjających okolicznościach ${ }^{114}$. Zdaniem Kasjana walka to narzędzie duchowego udoskonalania się $e^{115}$ i świadectwo miłości ${ }^{116}$. Próba, jak intuicyjnie wyczuwał Grzegorz Wielki, to balansowanie między dwoma punktami krańcowymi: „Błogosławiony Hiob znalazł się pośrodku między Bogiem a szatanem jako przedmiot sporu"117. Ojcowie pustyni zestawiali postawę Hioba z opisem klęski, jaką poniósł człowiek w raju. „Zawsze potrzebne jest właściwe usposobienie duszy” - zaleca jeden ze starców. „Adam chociaż był w raju, złamał Boże polecenie. Hiob zaś siedzący na gnoju zachował je"118. Mimo ewidentnego przykładu umiłowania Boga i posłuszeństwa $\mathrm{Mu}$, mistrzowie życia duchowego zdawali obie sprawę z trudności, jakie doświadcza przeciętny mnich, napotykając przygotowane przez złego ducha pokusy. Stąd konieczność położenia akcentu na walkę duchową.

Szczególnym przykładem osoby walczącej z podstępami złego był Antoni Egipski, który doświadczył jego działania na sobie w sposób szczególnie wyraźny i bolesny. Według Vita Antonii działanie szatana intensyfikowało się. Diabeł działał przez pokusę i zachętę do złego czynu, starając się by zło rozlało się

Wszystkich zamkniętych w więzieniu pobudza do walki podobne i jedno pragnienie cnót"; Cyprian z Kartaginy, Epistula 10.

111 Ewagriusz Pontyjski, Practicos 73.

112 Por. Homiliae in ep. ad Philemonem XIV.

113 Por. Homilia in Ps 66,8.

114 Por. Epistula 12.

115 Por. Collationes XVIII,13.

116 Por. tamże IV,6-7.

117 Moralia in Job, praef. 3,8.

118 Apophtegmata Patrum (seria systematyczna) XI,22. 
jak najszerzej ${ }^{119}$. Przybierał różne postaci, przede wszystkim zwierzęce i monstrualne. To prawdziwe bestiarium pustynne, atakujące fizycznie pustelnika ${ }^{120}$. Metropolita Aleksandrii Atanazy opisując swego bohatera tworzy paralelizm z historią Hioba, ukazując do czego może posunąć się diabeł, gdy Bóg da mu swobodę działania. Tak więc Antoni toczył otwarte boje $z$ demonami, wychodząc zawsze obronną ręką z tych potyczek, bowiem do walki z szatanem przystępował w zjednoczeniu z Chrystusem. Później Grzegorz Wielki dopowie, wskazując, że Job jako „ten, który wytrzymał zmagania duchowej walki..., opowiedział dzieje odniesionego zwycięstwa" ${ }^{21}$. Działanie demonów dotykało także kobiet, które oddały się życiu ascetycznemu. O świętej Melanii powiedziano, że „nieprzyjaciel, skoro zdał sobie sprawę, że nic nie otrzymuje walcząc przeciwko niej i że jako pokonany przydaje jej tylko większej chwały, zmieszany nie śmiał już jej niepokoić"122. Bolesne doświadczenie były więc jedynie narzędziem prób, poprzedzającymi zwycięstwo. Walkę ze złem rozumiano jako konieczność, bowiem zwalczanie wad i unikanie grzechu należy do głównych zadań człowieka. O słabości nie należy zapominać, jak przestrzega jeden z Apoftegmów, opowiadający, że „.do abba Zenona przyszli kiedyś bracia z pytaniem: "Co znaczą słowa z księgi Hioba: Nawet niebo nie jest dość czyste przed Bogiem» (Hi 15,5). Starzec odrzekł: «Zapomnieli ludzie o własnych grzechach, a badają grzechy niebios. Słowa te znaczą: ponieważ jedynie Bóg jest czysty, nawet niebiosa nie są czyste wobec Niego»"123.

W egzegezie Grzegorza Wielkiego obecne jest odniesienie do historii Hioba do walki wewnętrznej o bardziej ogólnym charakterze. Dzięki fabule i dramatycznym wypowiedziom wątek ten przemawiał z całą mocą do ówczesnych chrześcijan. W tym zmaganiu uczestniczył każdy z wiernych. „Synowie” sprawiedliwego męża $\mathrm{z}$ ziemi Us to, według interpretacji moralnej papieża, dobre myśli, pomiędzy które „podstępnie wdziera się ów odwieczny wróg, aby [je] zamącić... Dla szatana okrążać ziemię znaczy przeszukiwać serca tych, którzy żyją w ciele i starać się znaleźć jakąś okazję do oskarżenia. Okrążył ziemię, gdyż osaczył ludzkie serca, by zabrać dobro i wprowadzić do umysłów zło" ${ }^{124}$.

119 Por. M. Borkowska, Twarze Ojców pustyni, Kraków 2001, s. 7.

120 Makary z Pustyni Egipskiej nie pozwalał się zastraszyć makabrycznym zjawom. Por. Apophtegmata Patrum (seria alfabetyczna) 456.

121 Moralia in Job, praef. 1,3.

122 Vita Melaniae 18.

123 Apophtegmata Patrum (seria alfabetyczna) 238. Por. również seria systematyczna $\mathrm{X}, 22$.

124 Moralia in Job II,38,63. Odnośnie do kwestii grzechu por. F. Castaldelli, Il meccanismo psicologico del peccato nei "Moralia in Job” di San Gregorio Magno, „Salesianum”27 (1965), s. 563-605. 
Papież nie bez powodu kierował uwagę na postać Hioba, który różnił się od innych ludzi przede wszystkim tym, że nie uległ zepsuciu, był sprawiedliwy i wierny Bogu. Hiob został pozbawiony majątku, dzieci i zdrowia za przyczyną diabła. Jego wierność jednak nie osłabła. Biskup Mediolanu Ambroży uważał, że chrześcijanin powinien naśladować Hioba, który milczeniem „ganił” swych rozmówców ${ }^{125}$. Milczenie dla mnichów było znamieniem pokory i uległości względem woli Bożej ${ }^{126}$, jak również należało do arsenału środków pożytecznych w walce duchowej. Jeden $\mathrm{z}$ mnichów powtarzał słowa: „Jakakolwiek trudność na ciebie przyjdzie, zwycięstwem nad nią jest milczenie"127.

Opisywanie dziwów natury to częsty topos u pisarzy postnicejskich. Nie zawsze ma on znaczenie kaznodziejskie, chociaż niewątpliwie nawiązują do teologii, która uformowała się po soborze w Nicei, według której człowiek odnajduje Boga podziwiając wspaniałość i harmonię stworzenia ${ }^{128}$. Drogę kontemplacji stworzenia dopełnia wnikanie we własne życie wewnętrzne. Nie tylko jednak tutaj można dostrzec wątki obecne w tekście Hi. Mnisi potrafili ujarzmić najdziksze bestie jak krokodyle (por. Hi 40,25-32) ${ }^{129}$ i hipopotamy (por. Hi 40,15-24) ${ }^{130}$. W przekazach biblijnych cechami smoka był obdarzony krokodyl (por. Hi 40,25), co skrzętnie wykorzystała literatura starożytna ${ }^{131}$. Zwycięstwo nad bestiami znamionuje doskonałość duchową. „Mnich odziany w dobre czyny jest jak kółko nałożone na nozdrza smoka (por. Hi 40,21); czy-

125 Por. De interpretatione sancti Iob II,2,5. Inne przykłady budującego milczenia to Zuzanna (por. De Joseph 5,26) i król Dawid (por. De officis ministrorum I,6,21).

126 Por. Apophtegmata Patrum (seria alfabetyczna) 287; 619; 629; 819. Por. Sh. Carruth, The Monastic Virtues of Obedience, Silence and Humility: A Feminist Perspective, „The American Benedictine Review" 51 (2000), s. 121-147.

127 Por. Apophtegmata Patrum (seria alfabetyczna) 611.

128 Do kontemplacji Boga można dojść więc także kosmologicznie. Doktrynę tego typu wypracowali już Apologeci, lecz to rozważania o charakterze ascetyczno - moralnym dały późniejszym autorom możliwość szerszego rozwinięcia tematu. Por. T. Spidlik, La spiritualità dell'Oriente cristiano. Manuale sistematico (Orientalia Christiana Analecta 206), Rzym 1985, s. 293.

129 Na grzbietach krokodyli pływali zarówno młodzi mnisi, jak i wypróbowani w cnocie święci eremici. Por. Apophtegmata Patrum (E. Nau) 62 i 294; Historia monachorum in Aegypto 4 i 11.

130 Święty starzec imieniem Bes jednym rozkazem przegonił niebezpiecznego hipopotama, który niszczył plony rolników. Por. Historia monachorum in Aegypto 4.

131 Augustyn z Hippony, zestawiając największe i najmniejsze ze stworzeń mówi o „olbrzymich smokach” i „najmniejszych robaczkach” (De civitate Dei XI,27). Symbolika chrześcijańska odwołując się do smoka podkreśla jego identyfikację z szatanem. Chrześcijanie powinni być szczególnie ostrożni wobec jego zasadzek. Świętość utożsamiano ze zwycięstwem nad „smokiem” - szatanem. 
sta bowiem dusza mnicha, wydając słodką woń duchową, pieczętuje nozdrza węża ${ }^{132}$, aby w nim nie czuł smrodu pożądań" ${ }^{133}$. Na kanwie spotkań ze złem ucieleśnionym jako monstrum, powstawały budujące opowieści ${ }^{134}$.

Przed uleganiem złu ostrzegał Ewagriusz Pontyjski. Czynił to bez odwoływania się do konwencji anegdotyczno-fantastycznej. Pisał po prostu, że w życiu mnicha może pojawić się „brak uczuć” lub acedia - obojętność, będące bezpośrednim następstwem całkowitego zwycięstwa demonów i ich namiętności nad duszą. To pewien rodzaj duchowej śmierci.: „W jej pamięci kara i sąd wieczny są już tylko jakby gołymi słowami, gdy tymczasem zupełnie «wyśmiewa ogniste trzęsienie ziemi» (Hi 41,20) ${ }^{135}$. Wprawdzie niby wyznaje Boga, jednak nie poznaje jego zarządzenia... Dusza zwraca się do grzechu... Tego demona sprowadzają przewlekłe myśli próżnej chwały"136. Ewagriusz stwierdza, że tego rodzaju demona z pewnością przepędzi widok cierpienia, dotykającego bliźnich, a także żal i współczucie, jakie ono wzbudza.

Papież Grzegorz Wielki nie ma wątpliwości, że cierpienia Hioba były czymś więcej niż tylko sprawdzianem. Bolesne próby umocniły go w sprawiedliwości i wzbogaciły duchowo: „Cierpienie sprawdza, czy ktoś, kto żył w spokoju, kocha naprawdę. Nieprzyjaciel upominał się o Hioba, by go pokonać, a uzyskawszy dostęp do niego, jeszcze go wywyższył. Pan łaskawie pozwolił na to, czego diabeł niegodziwie żądał. Bo gdy nieprzyjaciel chciał dopaść Hioba, by

132 Smok to również wąż o ogromnych rozmiarach. Z tego powodu natchnione teksty używają określenia „smok” i „wąż” zamiennie. Chrześcijański erudyta ze schyłku antyku Izydor z Sewilli pisze w swoich Etymologiach, że „smok jest największym z węży i najpotężniejszym ze stworzeń na ziemi”; tamże XII,4,4).

133 Hyperchios, Adhortationes ad monachos 156 (157). Zło moralne utożsamiano z nieznośnym fetorem. „Grzechy nasze wydają zły zapach, są zgnilizną. Jeśli jednak będziemy za nie czynili pokutę..., rozkładające się grzechy nasze staną się wonnym olejkiem dla Pana”; Hieronim ze Strydonu, Commentarius in Marcum 1.

134 Grzegorz Wielki opisuje, że pewien młody mnich doświadczył zła w jego demonicznej postaci. „Uległ [on] pokusie niestałości i nie chciał pozostać w klasztorze... [i] za żadną cenę nie zgadzał się żyć dłużej we wspólnocie, tylko wciąż usilnie prosił, by go puszczono”. Gdy wreszcie opuścił krąg monastyru i „zaledwie... z klasztoru wyszedł, ujrzał na drodze smoka, który groził mu szeroko otwartą paszczą. Widząc, że zamierza go pożreć, cały drżący, zaczął wołać wielkim głosem: «Chodźcie szybko, bo smok mnie pożre»! Przybiegli bracia, nie zobaczyli jednak żadnego smoka, ale przerażonego i roztrzęsionego mnicha przyprowadzili z powrotem do klasztoru. Od razu też złożył przyrzeczenie, że nigdy klasztoru nie opuści i od tej chwili pozostał swemu przyrzeczeniu wierny. Modlitwy świętego [Benedykta] pozwoliły mu bowiem ujrzeć przed sobą tego smoka, za którym, nie widząc go, szedł poprzednio" (Dialogorum liber XXV,1-2).

135 Tekst wg LXX.

136 De malignis cogitationibus 11. 
go zniszczyć, On sprawił, że podczas kuszenia jeszcze wzrosły jego zasługi”137. Czytelnik księgi Hioba powinien więc zdać sobie sprawę, że cierpienie jest środkiem - a nie celem - do ukazania relacji człowieka do Boga. Dla każdego z ludzi odkrycie i spotkanie Boga, otwierające na nieskończoność, wyzwala z dramatu i uwikłania z powodu słabości.

Jak podkreśla autor Moraliów, Bóg nie przestał okazywać swego miłosierdzia wydanemu w ręce nieprzyjaciela sprawiedliwemu: „Opatrzność Boża strzeże swego wybranego również wtedy, kiedy go opuszcza; jedne jego dobra wystawia na niebezpieczeństwo, inne ochrania. Gdyby bowiem całkowicie oddała Hioba w ręce tak potężnego przeciwnika, cóż zdziałałby człowiek? Zatem do tego sprawiedliwego pozwolenia [jakiego Bóg udzielił szatanowi] została dołączona pewna doza miłosierdzia, jako że w wyniku jednej i tej samej walki pokorny sługa odnosi korzyść z ucisku, a pyszniący się nieprzyjaciel, choć mu ustąpiono, ponosi klęskę"138.

Teodoret, biskup Cyru ze szczególnym upodobaniem odnajdywał i opisywał epizody świadczące o „mocy prorockiej i apostolskiej” mnichów syryjskich ${ }^{139}$. Godni podziwu szczególnie byli ci, którzy cierpliwie znosili słabości i przeciwności. Najsławniejszy z mnichów syryjskich żyjący na wysokiej kolumnie Szymon Słupnik, według relacji Teodoreta z Cyru był godzien najwyższego podziwu ze względu na swoją wytrwałość w trudach i cierpieniach: „Mówią, że pozycja wyprostowana sprawiła, że zrobił mu się złośliwy wrzód na obydwu stopach, tak, że one ciągle i obficie ropieją. Mimo swych cierpień wcale nie odstępuje od swoich praktyk, lecz dzielnie znosi cierpienia z własnego wyboru i te, które nie zależą od jego woli... [Ponadto] jest niezwykle pokorny [...], uprzejmy, delikatny i łagodny" ${ }^{140}$. Podobnie jak biblijny Hiob Szymon Słupnik zachował równowagę ducha mimo cierpienia psychicznego i fizycznego. Biskup Cyru wskazuje wiernym, jak wielce doświadczani są ludzie przynależący do Chrystusa.

Refleksja chrześcijańska zrewaloryzowała cierpienie, tworząc nawet swoistą „teologię choroby"141. W kręgach ascetycznych nietrudno było znaleźć, tych, którzy często medytowali nad dolegliwościami fizycznymi, które ich dotyka-

\footnotetext{
137 Moralia in Job, praef. 3,7.

138 Tamże III,5,6.

139 Historia religiosa VI,5. Biskup Cyru zasięgnął informacji u godnych zaufania świadków i zrelacjonował własne doświadczenia.

140 Teodoret z Cyru, Historia religiosa XXVI.

141 Por. J.-C. Larchet, Théologie de la maladie, Paryż 1991.
} 
ły ${ }^{142}$. Jednak obok słabości i chorób, które miały przyczyny jak najbardziej naturalne, mnisi odkrywali dolegliwości i ułomności o wiele bardziej tajemnicze. Bolesne doświadczenia i cierpienia zsyłane przez Boga jako kara za winy lub jako środek oczyszczenia ze złych skłonności ${ }^{143}$. Ponadto asceci chrześcijańscy postrzegali bóle fizyczne jako próbę cierpliwości i jej konkretne świadectwo ${ }^{144}$. Dolegliwości ciała stały się lekarstwem duszy ${ }^{145}$. Znoszeniu bólu i cierpienia ${ }^{146}$ pomnażało zasługi mnichów oraz czyniło ich podobnymi do starotestamentalnych proroków ${ }^{147}$ i męczenników ${ }^{148}$.

Ciężkie choroby i fizyczna niemoc to znaki wzbudzające zgorszenie i prowokujące do pytań. Tak jest w przypadku relacji Palladiusza, który opisuje mnicha Benjamina ${ }^{149}$. „Przeżył [on] osiemdziesiąt lat, a... mimo że był obdarzony łaską [uzdrawiania], na osiem miesięcy przed śmiercią sam zachorował na puchlinę wodną. Ciało jego spuchło do tego stopnia, że wyglądał jak drugi Hiob (por. Hi 2,7). Biskup Dioskur ${ }^{150} \ldots$ powiedział [do mnichów]: «Chodźcie

142 W literaturze monastycznej znajduje się przykład „wzorcowej medytacji” na temat bólu i doświadczenia słabości. Przypisuje się ją Ewagriuszowi. „Myśl o nieszczęściu, przyjmij ból, niech cię lękiem napawa próżność tego świata. Bądź uważny i strzeż się, byś zawsze mógł pozostawać w tym skupionym usposobieniu, a nie osłabniesz". Apophtegmata (seria systematyczna) 227.

143 „Cierpienie spowodowane chorobą cielesną unicestwia to, co należy do tego świata, a my ukochaliśmy śmierć, by uwolnić się od bólu"; Teodor, Catechesis III,10. Por. L. Cremaschi (wstęp, tłum. wł i przypisy), Pacomio e i suoi discepoli. Regole e scritti, Magnano 1988. Odnośnie do ogólnej tematyki por. J.C. Larchet, Il buon uso della malattia secondo i Padri, „Communio" 154/5 (1997), s. 32-40.

144 Por. M. Casey, The Virtue of Patience in the Western Tradition, „Cistercian Studies” 21 (1986), s. 3-23.

145 Por. Vitae Patrum V,7,16-17. Por. A. de Vogüé, Medicina, w: G. Pelliccia-G.C. Rocca (red.), Dizionario degli Istituti di Perfezione, t. 5, Rzym 1974-1988, kol. 1125.

146 Czyniono to $\mathrm{w}$ duchu ewangelicznym. Zarówno mężczyźni, jaki i kobiety, czy to w samotności, czy to we wspólnotach zakonnych przez swój sposób życia starali się naśladować Chrystusa. W Nowym Testamencie przykładem człowieka prowadzącego rygorystyczny tryb życia był św. Jan Chrzciciel, a także św. Paweł, który zachęcał do zachowywania celibatu. Por. M. Kanior, Historia monastycyzmu chrześcijańskiego, t. 1, Kraków 1993, s. 10.

147 Por. przede wszystkim M.C. Paczkowski, Lo Spirito della profezia nel monachesimo antico, „Liber Annuus SBF” 47 (1997), s. 171-208.

148 Św. Ambroży z Mediolanu przypominał, że „dziewictwo czyni męczennikami”; De virginibus I,100.

149 Jeden z pierwszych uczniów Ammuna, cudotwórca, dotknięty straszliwą chorobą. Por. Sozomen, Historia ecclesiastica VI,29,9-10.

150 Wspomniany być może w Historia Lausiaca X,1. Był wtedy kapłanem, lecz później został patriarchą Aleksandrii (444-451), po Cyrylu Aleksandryjskim. 
zobaczyć nowego Hioba; ma opuchnięte ciało i cierpi na nieuleczalną chorobę, a okazuje Bogu wdzięczność bez miary». Poszliśmy i ujrzeliśmy... Nie mogliśmy patrzeć na tak straszne cierpienie i odwróciliśmy wzrok. Wówczas błogosławiony Beniamin powiedział do nas: «Módlcie się raczej, dzieci, aby mój człowiek wewnętrzny nie zachorował na puchlinę, gdyż to ciało na nic mi się nie przydało, kiedy byłem zdrowy, i wcale mi nie szkodzi, gdy choruję» ${ }^{151}$. Przez całe te trzy miesiące siedział na szerokim krześle, ponieważ już nie mógł położyć się w łóżku. A choć sam chorował, uzdrawiał innych"152.

W powszechnym przekonaniu mnichów choroba była pożyteczna dla duszy. Środowisko ascetów było więc dalekie od chorobliwego przeceniania i egzaltowania choroby. Palladiusz tłumaczy, dlaczego pisał ten epizod. Stało się to po, „byśmy nie zdumiewali się, jeśli jakaś przykrość przytrafi się sprawiedliwym ludziom" ${ }^{153}$. Podobną myśl wyraził Bazyli Wielki, podkreślając, że Bóg „pozwolił niektórym zmagać się z cierpieniami, aby prowadzić ich poprzez próby do większej doskonałości”" ${ }^{\prime 54}$. Cierpienie cielesne nie powinno być uważane za największe zło, bowiem „[Bóg] sprowadza chorobę na tych, dla których pożyteczniej jest mieć skrępowane ciało, niż bez przeszkód poruszać się ku grzechowi”"155. Według Bazylego Wielkiego losy Hioba wskazują, że „Niekiedy spadają choroby na żądanie Złego, gdy miłujący ludzi Pan dozwala, aby ktoś jakiś wielki wojownik - stanął do walki z Nieprzyjacielem i pokonał jego pychę nieskończoną cierpliwością swoich sług. Wiemy, iż to przydarzyło się Hiobowi (por. Hi 2,6). [W ten sposób] Bóg chce tym, którzy nie potrafią znosić bólu, dać przykład wytrwałości w cierpieniu aż do śmierci”" 156 .

Dramatyczne pytania wywołane tekstem księgi Hioba nie przestawały jednak nurtować ascetów. Ewagriusz z Pontu ostrzegał, że chociaż smutek „czyni anachoretę wypróbowanym... [Jednak] kiedy dłużej się utrzymuje, rodzi myśli, które doradzają duszy potajemne odejście [z ciała] albo przymuszają [anachoretę] do dalekiej ucieczki z miejsca [swego przebywania] ${ }^{157}$. Nad tym właśnie

151 Beniamin odwołuje się do alegorycznej wykładni hydropii. Por. Ewagriusz z Pontu, Capitula 16.

152 Historia Lausiaca XII,1-3.

153 Tamże XII,3.

154 Regulae fusius tractatae 55,2. Na temat obecności tekstu Hi u Ojców Kapadockich por. L. Carnevale, Giobbe dall'antichità al medioevo, s. 71-75.

155 Bazyli Wielki, Quod Deus non est factor malorum 3.

156 Regulae fusius tractatae 55,2.

157 Wyobcowanie (xeniteía-peregrinatio) to jedna z podstawowych kategorii duchowości i praktyki monastycznej. Ten sposób życia był uważany przez niektórych jego przedstawicieli za formę „wygnania”, ponieważ „mnich nie może osiągnąć doskonałości w swojej ojczyźnie” (Hieronim ze Strydonu, Epistula 14,7). Odnośnie do tej kwestii por. A. Guillau- 
zastanawiał się kiedyś i doświadczył tego święty Hiob, któremu naprzykrzał się ten demon. Powiada [Hiob]: «O, gdybym mógł samego siebie zgładzić bądź prosił przynajmniej kogoś innego, aby to dla mnie uczynił» (Hi 30,24)"158. Księga Hioba prowokowała rozmyślania na temat śmierci, które zalecali starożytni mistrzowie życia duchowego . Mnich - asceta powinien żyć „jakby miał umierać codziennie"159. Był to również wątek, który preferowano w medytacji ${ }^{160}$, co z pewnością miało na celu oderwanie mnicha od spraw doczesnych i skierowanie jego myśli ku wieczności. Podejmując walkę Hioba i naśladując jego cierpienie, człowiek doskonały będzie jak ten sprawiedliwy „oglądał Boga w tym ciele"161.

mont, Le dépaysement comme forme d'ascèse dans le monachisme ancien, w: tenże, Aux origines du monachisme chrétien, Bellefontaine 1979, s. 89-116.

158 De malignis cogitationibus 13.

159 Jan Kasjan, Institutiones V,41. Por. Atanazy, Vita Antonii 19; 69; Nemezjusz z Emezy, De natura hominis 1. Rozmyślania o śmierci zalecali Platon (por. Fedon 67 d) i Seneka (Epistulae morales ad Lucilium 12 i 61).

160 Por. Apophtegmata (manuskrypt Coislin) 182; 522; 531; Apophtegmata (seria systematyczna) 230; Gerontikon (abba Ewagriusz) 4; Jan Klimak, Scala paradisi 6. Podobną zasadę wyznawał Ambroży z Mediolanu (por. De excessu fratris Satiri II,35).

161 Ewagriusz Pontyjski, Epistula I,2. 
